\title{
MERAWAT RUANG BERSAMA DALAM PERBEDAAN DI PUSARAN KONFLIK SOSIAL BERATASNAMAKAN AGAMA
}

\author{
Oleh: \\ Liliya F. K. Wetangterah
}

\begin{abstract}
:
Religion is a peacemaker, but Indonesian history proves that religion is often used as a lighter of social conflict by various parties who want to take advantage. The diversity possessed by the Indonesian people must be able to be addressed and managed well. Creating a shared space in different places, places or containers of different parties becomes a necessity in the midst of this diversity. Shared spaces in difference are needed to prevent conflict. These differences can compartmentalize people to see different parties as others. Shared space in difference also becomes a necessity that must be created in the midst of conflict situations though. Lian Gogali who collected stories about the common space in the Poso conflict proved that the common space in the conflict was not impossible. Creating shared space in difference is part of the church's duties as a realization of the reconciliation mission. The mission of selfreconciliation has actually been done by God himself and therefore must be continued as the church's duty.
\end{abstract}

Keywords: Religion, diversity, self-reconciliation, conflict, shared-space.

\section{Pendahuluan}

Pilkada Jakarta yang sempat menaikan tensi suhu politik, ternyata tidak hanya dirasakan di Jakarta tetapi hampir di seluruh Indonesia. Kota Kupang yang menjadi ibu kota dari provinsi Nusa Tenggara Timur (NTT) juga terkena dampak memanasnya suhu politik Jakarta. Seperti yang terlihat dalam debat-debat di status-status Facebook maupun pembicaraan di ruang-ruang publik seperti pasar, mall, angkutan umum dan ruangruang kantor. Puncak memanasnya suhu politik di Kota Kupang terjadi pada saat pembacaan keputusan dan eksekusi penahanan Ahok selama dua tahun.

Keputusan ini banyak membuat masyarakat kota Kupang menjadi marah dan melampiaskannya dengan berbagai cara. Sebagian masyarakat memilih untuk membakar lilin di depan kantor-kantor pemerintahan, sebagian lagi berinisiasi untuk melaksanakan konser kebinekaan, dan sebagian memilih untuk melampiaskan perasaan mereka dengan menulis-kannya pada status 
facebook. Rasa simpati kepada Ahok tidak hanya keluar dari penghargaan terhadap kinerja Ahok yang berani melawan dengan tegas para koruptor. Bagi masyarakat kota Kupang, identitas Ahok sebagai seorang pemimpin beragama kristen melahirkan rasa ikatan emosional tersendiri sebagai sesama orang kristen. Keadaan ini terlihat jelas dari komentarkomentar dan status facebook yang tidak segan-segan untuk menyamakan Ahok dengan kepemimpinan Yesus. Kepemimpinan Ahok sebagai tokoh yang dengan berani mengambil resiko untuk memberantas korupsi, berpihak pada masyrakat kecil dan membela kebenaran disamakan dengan cerita Tuhan Yesus yang akhirnya disalibkan karena kebenaran. Berbagai ayat Alkitab dikutip dan doa-doa dinaikan untuk menggambarkan dukungan kepada Ahok agar Ahok mampu untuk melewati seluruh proses peradilan dengan baik.

Selain status facebook yang menyamakan Ahok dan Yesus terdapat banyak juga cekaman terhadap tindakan intolenrasi yang terjadi di Jakarta. Kecamankecaman yang ada diikuti dengan ajakan untuk mencontohi praktek toleransi beragama yang selama ini berlaku di NTT.

Kecaman terhadap toleransi dan ajakan untuk mencontohi toleransi ini tiba-tiba terusik oleh status salah seorang teman muslim yang mempertanyakan dengan kritis toleransi yang sedang berlangsung di NTT. Prima seorang ibu muda, dalam status facebook memberikan beberapa contoh tindakan yang baginya membuktikan bahwa toleransi yang ada di NTT tidak seperti yang dipuji selama ini. Prima memberikan contoh betapa bebasnya penjualan daging babi hingga dipinggiran jalan-jalan utama, pembakaran daging babi yang berakibat pada menyebarnya asap, dan bagaimana orang kristen begitu mudah memberikan salam dengan berciuman atau bersalaman ketika baru saja selesai memakan daging babi. Contoh-contoh yang diungkapkan oleh Prima memang sudah menjadi pemandangan sehari-hari dari kehidupan di kota Kupang.

Gugatan Prima melalui status facebook tersebut disambut dengan komentar yang penuh kemarahan dari masyarakat. Dengan cepat status tersebut diviralkannya menimbulkan banyak sekali reaksi negative. Prima mendapat berbagai macam komentar kasar, ancaman hingga laporan ke pihak polisi yang berakhir dengan penanggakapan dirinya. Pelaporan Prima ke polisi dengan alasan bahwa Prima melakukan penyebaran ujaran kebenciaan 1 Penangkapan ini memang disesalkan oleh berbagai pihak namun sebagian orang berpendapat bahwa penangkapan tersebut adalah sebuah tindakan yang tepat pada situasi saat itu. Jika saat itu pihak kepolisian tidak melakukan

\footnotetext{
1Perempuan penyebar kebencian resmi ditahan, https://www.nttnews.com/2017/05/15/perempuanpenyebar-ujaran-kebencian-resmiditahan/. 15 Mei 2017, diakses 31 Agutus 2017.
} 
penangkapan maka pengadilan masa yang akan bertindak. Dengan ditangkapnya Prima kemarahan masyarakat kota Kupang terhadap tindakan intoleransi yang dialami oleh Ahok "seolah tersalurkan". Prima seolah menjadi "pertukaran kasus" dengan apa yang terjadi pada Ahok. Reaksi untuk mendukung dan menolak penangkapan Prima terus menjadi hangat, namun berakhir dengan rekonsiliasi antara pihak pelapor dan Prima beserta keluarganya. ${ }^{2}$ Prima akhirnya bisa merasakan puasa dan ramadhan bersama keluarga.

Konflik perebutan kursi gubernur Jakarta berubah begitu cepat menjadi gesekan di masyarakat kota Kupang. Siapapun gubernur Jakarta yang terpilih tidak akan berpengaruh langsung pada kehidupan masyarakat kota Kupang. Namun ketika politik menyentuh isu agama masyarakat kota Kupang yang berbeda pulau pun seolah merasa turut bertanggungjawab dengan keadaan Jakarta.

\section{Sensitifnya Isu Agama:}

Kasus Ahok dan Prima adalah dua kasus yang berbeda namun saling berkaitan. Dari dua kasus ini terlihat dengan jelas bahwa identitas agama adalah sesuatu yang sensitif. Agama seolah menjadi "batu pijakan" ampuh

\footnotetext{
2 Tarik Laporan, Brigader Meo Maafkan Prima Gaida Journalita, https://www.nttnews.com/2017/06/07/tarik-laporanbrigade-meo-maafkan-prima-gaidajournalita/. 7 Juni 2017, diakses 31 Agutus 2017.
}

untuk merebut kekuasaan namun pada saat yang berasamaan, isu agama dapat berubah menjadi pemantik yang dengan mudah menyulut api konflik di tengah masyarakat. Di Jakarta, Ahok seorang kristen dari kelompok minoritas berhadapan dengan kelompok muslim yang dominan. Di Kupang, sebagai efek dari Pilkada Jakarta, Prima seorang ibu muslim dari kelompok minoritas berhadapan dengan kelompok kristen yang dominan. Agama yang pada hakikatnya memberitakan kedamaian menjadi sangat sensitif dan dapat digunakan sebagai pemantik konflik sosial.

Menurut Emil Durkheim, agama dalam analisis sosiologi memiliki definisi fungional yang menempatkan agama sebagai inti masyarakat. Agama menentukan perspektif penganutnya dalam memandang dan mengerti dirinya sendiri serta relasinya dalam masyarakat. ${ }^{3}$ Agama adalah satu kesatuan antara sistem kepercayaan dengan praktik-praktik sosial yang dianggap suci serta berfungsi untuk mengatasi persoalan-persoalan utama manusia. 4 Pendapat lain menandai agama dari enam ciri yaitu ajaran (doctrine), mito (myth), etika (etichs), ritual, pengalaman dan lembaga-lembaga sosial. ${ }^{5}$ Agama menjadi identitas

${ }^{3}$ A. A. Yewangoe, Agama dan Kerukunan, (Jakarta: Gunung Mulia, 2011)3.

4 Basilica Dyah Putrani, Perempuan, Konflik, dan Rekonsiliasi, (Jakarta: Gunung Mulia, 2016)77.

${ }^{5}$ Anderas A. Yewangoe, Tak Ada Negara Agama, (Jakarta:Gunung Mulia, 2009)31. 
diri seseorang dan komunitas pengikutnya.

Selain definisi fungsional tersebut, agama juga bersifat ambigu dapat membebaskan tapi sekaligus memperbudak. 6 Sifat pembebasan agama telihat ketika agama memungkinkan pengikutnya untuk berhubungan dan bergaul dengan orang lain yang berbeda tanpa tekanan atau beban tertentu. Sementara sifat agama yang memperbudak terlihat dari sikap Triumfantilisme atau sikap memang sendiri, merasa unggul dari yang lain. Sikap ini akan menempatkan pemeluk agama lain sebagai warga kelas dua dalam masyarakat. Saat agama diserang atau digugat oleh orang lain, kekerasan dapat digunakan untuk menyatakan ketidaksetujuan oleh kelompok agama yang dominan terhadap kelompok agama yang rentan. Agama menjadi isu yang sangat rentan, dan ampuh dipakai sebagai pemantik konflik sosial. Peringatan Marx dapat menjadi relevan, baginya agama adalah suatu bentuk kesadaran palsu yang dimanfaatkan oleh kelas penguasa untuk memperlkuat dominasinya, dengan menetapkan apa yang benar menurut para penguasa sebagai apa yang benar bagi keseluruhan. ${ }^{7}$

Laporan tahunan Wahid Institue tentang kemerdekaan beragama/berkeyakinan (KBB) di Indonesia menjelaskan bahwa terdapat kenaikan 20\% peristiwa pelanggaran kebebasan beragama/

\footnotetext{
${ }^{6}$ Putrani, Perempuan, Konflik, dan Rekonsiliasi, 93.

7 Ibid, 77.
}

berkeyanikan dari tahun 2014 meningkat pada tahun 2015. 8 Selama tahun 2014 terdapat 158 peristiwa dan 187 tindakan sementara tahun 2015 menjadi 190 peristiwa dan 249 tindakan. Kenaikan ini terjadi dikarenakan tidak adanya perubahan signifikan dari pola penanganan kasus-kasus pelanggaran KBB oleh pemerintah. Keadaan ini mengakibatkan korban terus mengalami pembiaran. Angka-angka ini tentunya akan terus meningkat dari tahun ketahun. Seperti yang terlihat dari pemberitaan media masa yang hampir setiap hari menyiarkan berita tentang kasus-kasus pelanggaran kemerdekaan beragama dan berkeyakinan.

Dengan melihat sejarah bangsa Indonesia, Yewangoe menjelaskan bahwa pada masa Orde Baru, agama-agama diajukan ke depan sebagai yang memberikan landasan moral, etika, dan spiritual bagi pembangunan nasional sebagai pengamalan Pancasil. 9 Keberaga-man agama yang ada membuat hal ini tidak mudah, ada yang kemudian membicarakan etika bersama sehingga pembangunan nasional bisa diarahkan dan dievaluasi. Di sisi lain, sebagian pendapat mengatakan bahwa pada masa itu agama terjebak di dalam sikap tidak kritis. Alih-alih

8Laporan Kebebasan Beragama dan Berkeyakinan 2015.

http://wahidfoundation.org/index.php/ publication/detail/Laporan-KebebasanBeragama-dan-Berkeyakinan-KBB-2015 diakses 31 Agustus 2017. Agama, 34. 
memberikan landasan moral etika, agama-agama lebih menunjukan sikap selalu setuju pada setiap upaya pembangunan kendati pembangunan tersebut tidak mencerminkan kehidupan yang mencerminkan keadilan, pemerataan, dan kesejahteraan.

Selanjutnya Yewangoe menjelaskan pada masa reformasi, agama juga ditonjolkan sebagai yang dapat menyelesaikan persoalan. Namun alih-alih menyelesaikan persoalan agama justru merupakan bagian dari persoalan itu sendiri. Konlik Ketapang, Konflik Ambon, Konflik Poso, pengrusakan dan pembakaran rumah-rumah ibadah, dan pelarangan membangun rumah ibadah kendati seringkali tidak dimotivasi oleh agama namun nuansa-nuansa agama begitu kental. Terlihat melalui penggunaan simbol-simbol agama baik sebagai pemberi spirit, simbol kekuatan maupun sebagai sasaran pemusnahan. Agama dipakai sebagai alat untuk tujuan tidak luhur yang justru bertentangan dengan keluhuran agama. Namun di sisi lain, agama-agama masih dapat memainkan peran penting di dalam upaya bersama menyelesaikan persoalan-persoalan bangsa.

Ambiguitas sifat agama yang membebaskan dan memperbudak tidak dapat disepelekan begitu saja. Hidup beragama dalam keberagaman berarti hidup dengan memberikan ruang seluas-luasnya bagi fungsi agama yang membebaskan. Sifat ambigu agama ini membuka pilihan bagi para pengikutnya untuk memilih dengan sadar sifat mana yang akan dikembangkan. Ketika wajah memperbudak dari agama dikembangkan maka agama akan dengan mudah menjadi pemantik konflik sosial. Namun jika dengan sengaja menyediakan ruang-ruang bersama agar berbagai perbedaan dapat saling bersentuhan maka keberagaman yang ada dapat dikelola dengan baik.

\section{Ruang Bersama untuk Mencegah Konflik}

Semua agama termasuk di dalamnya agama-agama suku, tentunya mengajarkan kasih dan penghargan terhadap sesama manusia. Walau kita lahir dan dibesarkan dalam komunitas beragama yang beragam, penuh dengan perbedaan namun sikap menghargai perbedaan tidak lahir begitu saja namun harus dengan sengaja ditumbuhkan. Individu atau komunitas yang tidak sama atau berbeda dengan identitas kita seringkali kita namakan dan tempat-kan sebagai Yang Lain.

F. Budi Hardiman, dalam bukunya Masa, Teror dan Trauma menjelaskan bahwa terdapat tiga cara pandang terhadap Yang Lain, dalam hubungannya dengan konflik-konflik sosial yang terjadi di Indonesia. ${ }^{10}$ Termasuk di dalamnya konflik yang menggunakan isu SARA sebagai:

${ }^{10}$ F. Budi Hardiman, Massa, Teror, dan Trauma, (Yogyakarta: Lamalera, 2011) 3-21. 
1. Yang Lain di antara kita

Pemahaman ini menyadari bahwa perbedaan adalah bagian dari kehidupan bersama. Yang berbeda itu ada tetapi mereka ada diantara kita, menjadi bagian dari kehidupan bersama. Pengakuan bahwa perbedaan sebagai bagian diantara kita tidak serta merta membuat kita menerima yang berbeda secara setara. Perbedaan ada diantara kita tetapi mereka tetap tidak setara.

Hardiman menjelaskan dalam kontak sosial kita menemukan orang-orang atau komunitas yang "menyimpang" dari standar "normalitas tertentu" yang dianut oleh mayoritas. Mereka dapat berciri sosial, kultural, ediologis, maupun religius seperti kaum homoseksual, musuh-musuh politis razim, pendatang asing, pengikut sekte terlarang, orang dengan gangguan jiwa dan lain sebagainya. Golongan ini sering diperlakukan sebagai Yang Ekstrem Lain karena konstruksi berpikir masyarakat mendikotomikan mereka. Seringkali mereka diobjekan sebagai objek penelitian, dipertontonkan sebagai hewan sirkus, atau seperti orang dengan gangguan jiwa yang diikat sebagai 'monster' peliharaan. Dalam masyarakat tahayul kelainan-kelainan ini dipercaya sebagai pengejahwantaan dari yang jahat atau kutukan dari Allah.
Jika sebagian yang berbeda dikelompokan sebagai Yang Lain diantara kita, sebagian lagi dikelompokan sebagai yang Yang Kurang sama. Orang-orang yang sangat kaya, kaum perempuan yang sangat cantik dan orangorang yang sangat pintar. Dalam perbandingan dengan mayoritas, mereka ini tidak ekstrem lain namun hanya orang yang tidak sama dengan mayoritas.

Dalam masyarakat majemuk yang toleran kelainan dan perbedaan dipersepsi tanpa ketakutan. Masyarakat toleren akan meng-integrasikan Yang Ekstrim Lain dan Yang Kurang Sama sebagai bagian dari hidup sehari-hari, bagian dari kita. Masyarakat yang memahami bahwa setiap individu dan seluruh identitasnya adalah bagian terpenting dari masyarakat akan melihat setiap individu sebagai sesama manusia. Yang sama menemukan dirinya melalui Yang Lain. Mereka, Yang Ekstrem Lain sekalipun hidup diantara kita menjadi elemen keseharian yang tidak perlu dipersoalkan.

Masyarakat seperti ini akan menyadari bahwa agama, ras, ideologi, dan identitas lainnya dari seseorang dapat berbeda namun kita semua adalah sama warga negara. Setiap warga negara dengan seluruh identitas yang dimilikinya adalah bagian terpenting yang tidak dapat diabaikan begitu saja. Menjadi satu warga negara yang sama 
tidak berarti menyeragamkan seluruh identitas kita.

2. Yang Lain di hadapan kita.

Pemahaman ini menggantikan kata "diantara kita" menjadi kata "di hadapan". Dalam pemahaman ini yang berbebeda atau yang lain dilihat secara konfrontative. Dengan cara mengambil jarak sosial tanpa kekerasan, merasa tak suka, mengabaikan sampai pada konflik dengan kekerasan.

Stigma adalah salah satu penghalang terjadi persentuhan sosial antar masyarakat yang berbeda. Melalui stigma rasa takut untuk bersentuhan diawetkan dan dipelihara. Pribadi-pribadi yang terkena stigma mendapas diskriminasi dan didehumanisasi. Kita yang mayoritas adalah yang normal dan pantas disukai. Namun berbeda dengan mereka yang terstigma dilihat sebagai sesuatu yang menjijikan dan pantas untuk dibenci atau bahkan dilenyapkan.

Stigma tidak hanya seolah membenarkan penghinaan bagi mereka yang terstigma, malainkan fobia. Dalam situasi konflik, suara dan keberadaan mereka yang terstigma dilihat sebagai ancaman terhadap keutuhan kolektif. Dengan stigma individu atau kelompok yang berbeda dikelompok-kelompokan satu dengan lainnya sehingga saling terisolasi dan takut untuk bersentuhan. Ketika kelompok telah terbentu dan tak ada ruang untuk bersentuhan maka mudah diadudomba. Stigma menghadap-kan kelompok untuk melawan kelompok. Paling nyata adalah politik devibe et impera: buatlah kelompok-kelompok yang ber-beda agama atau etnis terisolasi dan takut untuk bersentuhan, dan berkuasalah.

Contoh stigma yang paling nyata dalam kehidupan berbangsa adalah stigma komunis kepada para korban Tragedi '65. Tanpa periksaan yang jelas, mereka distigma oleh Orde Baru sebagai penghianat bangsa. Sebagai orang yang tidak berTuhan sehingga harus dijauhi bahkan seluruh hak sebagai warga negara didiskriminali-sasikan. Contoh lain nyata dari pemahaman Yang Lain di hadapan kita terlihat pada kerusuhan Mei 1998. Pada saat itu banyak sekali perempuan kristen dari golongan tionghoa banyak mengalami pemerkosaan. Pelaku pemerkosaan pada situasi konflik, melihat dan menempatkan kaum perempuan tersebut, tidak sebagai sesama warga negara atau sesama manusia namun sebagai orang kristen yang terstigma sebagai pendatang yang dimusuhi sehingga layak dilecehkan. Pola pengelompokan dengan membangun stigma yang kemudian memicu konflik juga terlihat jelas pada konflik Ambon dan Poso. Masyarakat yang sebelumnya telah hidup dengan saling menghargai dari generasi ke generasi, dalam waktu singkat 
berhadap-hadapan dalam konflik bahkan saling menyerang dan membunuh sesama saudara.

\section{Yang Lain di dalam kita}

Pembagian yang terakhir ini adalah Yang Lain di dalam kita. Kata di dalam kita bermakna bahwa rasa takut terhadap yang lain bersumber dari dalam diri kita. Ketakutan lahir dari pemikiran kita sendiri. Ketika telah ada ketakutan dalam diri kita terhadap yang lain, perbedaan yang tidak terlalu mencolok pun akan dilihat sebagai ancaman dan menakutkan. Ketakutan terhadap yang lain sebenarnya berakar pada ketakutan terhadap diri sendiri atau kepentingan diri sendiri.

Kesamaan ideologi, agama, atau etnik menjadi alat penegasan diri sebagai "ego kolektif" yang kemudian akan terancam jika berhadapan dengan yang lain. Yang Lain, menjadi simbol yang jahat karena itu melenyapkan mereka menjadi dibenarkan secara etis. Perubahan dan kemajemukan dipahami dalam diri sebagai ancaman terhadap kepentingan kolektif.

Contoh dari pemahaman ini terlihat pada bagaimana ketakutan dari sebagian masyarakat terhadap gay atau lesby. Rasa takut dalam diri untuk berkomunikasi dengan LGBT karena takut akan tertular, pemikiran sendiri yang mengandaikan bersalaman dengan umat beragama lain sebagai sesuatu yang najis, dan takut bersentuh dengan kasta lain karena akan menodai diri menjadi contohcontoh bagaimana ketakutan terhadap yang lain lahir dari pemikiran diri sendiri.

Ketiga pembagian ini menegaskan bahwa ruang-ruang komunikasi, ruang untuk saling bersentuhan, dan membangun relasi dengan yang berbeda tidak hanya penting melainkan suatu kebutuhan. Ruang-ruang bersama bagi perbedaan ini akan melihat gam-baran Yang Lain sebagai gambaran yang harus dipersoalkan, direlati-fikasikan, dan akhirnya ditinggalkan. Pengetasan prasangka dan sikap intoleran dimungkinkan terjadi pada manusia yang tidak cemburu karena mempunyai keluasan pengalaman. Dengan ruang-ruang bersama perbedaan tidak dihapuskan tetapi dikenali dan kerena itu tidak menjadi ancaman yang harus ditakuti. Dengan demikian perbe-daan tidak mudah berubah menjadi konflik sosial.

Kelompok agama yang menjadi dominan di satu daerah berkewajiban untuk keluar dari zona nyaman untuk bertemu dan bersentuhan dengan kelompokkelompok agama yang minoritas. Pendidikan agama tidak hanya berkewajiban untuk memperkuat iman pengikutnya. Pendidikan agama juga berkewajiban membangun ruang-ruang bersama untuk saling mengenal agama lain yang berbeda. Sekolah-sekolah agama yang menerima siswa dan 
mahasiswa dari satu latar belakang satu agama berkewajiban untuk dengan sengaja menyediakan ruang-ruang bersama dengan pemeluk agama lain. Pendidikan agama berkewajiban untuk menjadi ruang bagi pengejawentahan fungsi agama yang membebaskan sehingga agama tidak mudah digunakan sebagai pemantik konflik sosial.

Salah satu contoh yang dapat diambil adalah mahasiswa STAKN Kupang. Kota Kupang adalah salah satu kota yang didominasi oleh penganut agama kristen, terletak di sebuah provinsi yang juga didominasi oleh penduduk beragama kristen, baik kristen protestan dan katolik. Dalam situasi seperti ini dengan mudah kita menemukan mahasiswa-mahasiswa yang tidak memiliki kawan beragama muslim sejak dari sekolah dasar hingga mahasiswa. Dalam keadaan seperti ini ruang-ruang bersama untuk saling bertemu, bersentuhan, dan berinteaksi dengan teman-teman muslim menjadi sangat penting. Tanpa ruang bersama dalam perbedaan, teman-teman muslim atau yang beragama lain akan tetap menjadi Yang Lain. Selanjutnya mahasiswa-mahasiswa ini kemudian menjadi guru-guru agama di berbagai sekolah atau menjadi guru-guru sekolah minggu tanpa memiliki pengalaman berada dalam ruang bersama dalam perbedaan dengan penganut agama lain. Pemahaman yang menempat-kan penganut agama lain sebagai mereka Yang Lain, kemudian diturunkan kepada para murid yang belum tentu akan memiliki kesempatan untuk bersentuhan dengan penganut agama lain. Pemahaman yang menempatkan penganut agama lain sebagai Yang Lain akan terus diproduksi dari satu generasi ke generasi. Situasi seperti ini dapat menjadi lahan subur bagi pihak-pihak yang ingin mengambil keuntungan politik atau ekonomi dengan menggunakan isu agama.

Dalam dunia pendidikan ruang-ruang bersama dalam perbedaan harus disediakan secara sengaja. Dengan menyediakan ruang bersama untuk saling bertemu antar pemeluk agama yang berbeda dapat memberikan pengalaman saling bersentuhan. Pengalaman tersebut dapat membuktikan bahwa perbeda-an agama adalah sebuah kenyataan yang tidak dapat dihindari tetapi harus dikelola dengan baik. Indonesia adalah rumah bersama dalam perbedaan.

\section{Ruang Bersama Saat dan Setelah Konflik: Belajar dari Poso}

$\begin{array}{ccr}\text { Penciptaan ruang } & \text { bersama } \\ \text { antar } & \text { agama tidak hanya }\end{array}$ dibutuhkan untuk mencegah konflik sosial. Dalam situasi konflik dan pasca konflik, penciptaan ruang bersama antar dua kelompok yang bertikai sangat dibutuhkan. Walau untuk merealisasikan hal tersebut bukan-lah perkara yang mudah dan tentunya tidak lagi mungkin mengambalikan kehidupan seperti saat sebelum konflik. Mekanisme inilah yang ditempuh oleh Lian Gogali dengan pengalamannya saat 
konflik Poso pada Desember 1998. ${ }^{11}$

Salah satu konflik yang cukup besar dan tetap membekas hingga sekarang adalah konflik Poso. Konflik Poso terjadi beberapa saat setelah pemilihan bupati pada Desember 1998 dan disulut oleh masalah yang dapat dikatakan sepele yaitu perelahian antarpemuda. Perkelahian ini kemudia berubah menjadi sebuah konflik besar yang memakan ribuan jiwa dan masih meninggalkan trauma yang cukup mendalam hingga saat ini.

Menurut Gogali, media masa dan publik mengenal konflik Poso sebagai konflik antara satu komunitas agama yang menghancurkan komunitas agama lain. Masyarakat Poso, "menyesuaikan diri" dengan isu yang berkembang di publik tentang adanya "perang antar komunitas agama, Islam dan Kristen. Masyarakat Poso yang dipaksa untuk menamai konflik Poso sebagai konflik agama melanjutkannya pada tindakan sehari-hari antar individu dan komunitas. Walau masyarakat Poso sendiri tidak tahu dari mana datang ide konflik agama tersebut.

Dengan menerima bahwa konflik Poso adalah konflik agama, maka tertutup ruang antara dua komunitas yang bertikai untuk membicarakan persahabatan, penyesalan yang memilukan, rasa kehilangan yang memilukan, dan kerinduan untuk hidup bersama.

${ }^{11}$ Lian Gogali, Konflik Poso: Suara Perempuan dan Anak Menuju Rekonsiliasi Ingatan, (Yogyakarta: Galang Pers, 2009)24.
Dengan tertutupnya ruang tersebut, masyarakat sehari-hari memproduksi cerita-cerita yang terbiasa memposisikan kedua kelompok secara berhadapan. Pengalamanpengalaman negatif bermunculan, diingat, dan direproduksi setiap hari, mengendap dalam ingatan membentuk perilaku dan citra seseorang atau komunitas, dalam skala yang lebih besar mengkonstruksi identitas suatu komunitas.

Pengalaman-pengalaman

negatif tentang pertikaian antar kelompok agama tidak hanya diterima oleh masyarakat Poso pada masa konflik namun juga berdampak pada masa depan. Yang membahayakan bagi masa depan adalah ketika generasi selanjutnya meneruskan dan ikut membenarkan narasi konflik yang negatif tersebut. Permusuhan menjadi dibiasakan, masing-masing kelompok melihat yang lain sebagai "hantu" kecurigaan, prasangka, dendam, kemarahan, mengikuti jejak kehidupan masyarakat Poso secara turun temurun. Poso akan diingat oleh negerasi Poso dan masyarakat lainnya sebagai daerah dengan konflik agama. Generasigenarasi penurus akan meneruskan cara berpikir ini dan menghidupinya. Pada titik inilah konflik dapat berdampak bagi hilangnya sejarah dan genarasi.

Bagi Gogali, rekonsiliasi ingatan masyarakat Poso menjadi penting karena identitas komunitas yang terbentuk akan tergantung pada pilihan untuk mengingat dan bagaimana bersikap terhadap ingatan. Ingatan bersama adalah 
puncak dari ingatan-ingatan komunal. Oleh karena itu rekonsiliasi ingatan harus dimulai dari rekonsiliasi ingatan-ingatan individu. Rekonsiliasi ingatan ini dilakukan dengan mengumpulkan kisah-kisah pertemanan, saling menolong, saling menyelamatkan, saling mendukung antara komunitas agama pada saat konflik. Kisah-kisah tersebut menunjukan bahwa di tengah konflik sekalipun ruang-ruang bersama dapat tercipta. Sayangnya kisah-kisah ini menjadi terpinggirkan, tidak dibicarakan ketika masyarakat telah beradaptasi dengan pemahaman bahwa konflik Poso adalah konflik antar agama.

Dalam penelitiannya, Gogali menemukan kisah para tetangga dan sesama saudara yang berbeda agama saling membantu untuk menyamar-kan identitas agama. Ketika terjadi pemeriksaan KTP dan isu penyerangan dari kelompok agama Islam maka saudara yang beragama Islam akan memberi peringatan awal dan melindungi tetangganya yang beragama kristen, demikian juga sebaliknya. Di beberapa poros jalan ke luar Poso, tempat biasanya dilakukan sweeping, beberapa orang yang lolos menceritakan dengan terharu bagaimana dalam satu rombongan berbeda agama mereka saling mengajarkan inti pokok ajaran masing-masing. Penggungsi kristen mengajarkan doa Bapa Kami kepada yang muslim dan yang kristen mengajarkan kalimat syahadat kepada yang kristen. Dengan demikian, ketika yang melakukan penodongan adalah kelompok muslim maka semua anggota rombongan dapat mengucapkan kalimat syahadat. Demikian juga sebaliknya, ketika yang melakukan penodongan adalah kelompok kristen maka semua anggota kelompok dapat mengucapkan Doa Bapa Kami.

Kisah lain, juga didapat dari para penggungsi yang memilih untuk menggungsi di hutan. Ketika bertemu dengan kelompok penggungsi lainnya di hutan, di kebun, siapapun dari agama mana pun saling membagikan makanan, bahkan saling menunjukan dimana letak tempat penyimpanan makanan. Ada juga cerita beberapa orang mengancam meyediakan dirinya untuk turut dibunuh saat kelompok yang mengatasnamakan agamanya akan membunuh kelompok yang berbeda agama. Upaya itu akhirnya berbuah manis sebab akhirnya seluruh kelompok penggungsi yang ada terselamatkan.

Kisah tentang terciptanya ruang bersama di tengah konflik tidak hanya datang dari para penggungsi tetapi juga dari para kombatan muslin dan kristen saat perang terbuka. Ketika kombatan dari dua kelompok berbeda agama ini saling berhadapan dan siap berperang, namun saat menyadari bahwa yang diperangi adalah teman, tetangga bahkan saudara, mereka justru berteriak untuk saling menasehati untuk mundur dan tidak jadi menyarang. Tidak jarang memilih untuk saling menanyakan kabar ayah, ibu, atau keluarga lainnya. Seorang pemimpin perang yang membawahi sekitar 500 orang bercerita 
bagaimana saat berada di Tayado, di tengah perang terbuka ia melihat salah satu teman kantornya dan mereka berdua akhirnya mengancungkan tanda jempol ke bawah yang kemudian dibalasnya juga dengan tanda yang sama. Tanda jempol ke bawah sendiri adalah tanda bahwa keduanya telah samasama kehabisan amunisi, hingga akhirnya kedua kelompok yang saling menyerang mundur bersama.

Sayangnya cerita-cerita seperti ini hanya terdengar dari kalangan akar rumput, masyarakat biasa. Cerita-cerita ini tidak terdengar oleh publik karena yang selalu diberitakan adalah ceritacerita bagaimana kedua kelompok saling menyerang. Kehidupan setelah konflik tidak lagi sama. Kepercayaan antar kelompok menjadi hilang satu dengan lainnya. Walau konflik sudah berlalu namun rasa curiga tetap tinggal. ${ }^{12}$ Kalimat "Hati orang siapa yang tahu? Menjadi penanda kecurigaan yang berkembang di tengah masyarakat setelah konflik. Penenada lain adalah penggunaan kata "Kitorang" dan "Dorang" selau dipakai saat menggambarkan kelompok agama yang berbeda. Demikian juga dengan pembagian wilayah juga menjadi berubah menjadi "wilayah kami" dan "wilayah mereka". Identitas agama tidak hanya menjadi pembedah tetapi menjadi pemisah yang cukup kuat. Masyarakat Poso hidup dengan terkotak-kotak oleh perbedaan agama. Tidak hanya pada ranah ucapan tetapi pada pembagian wilayah pun mereka telah terpisahkan.

Dengan mengumpulkan
kembali cerita-cerita tentang
bagaimana terciptanya ruang-ruang bersama ketika konflik, masyaraka dibantu untuk mengkritisi dan mempertanyakan kembali pemahaman publik mengenai konflik agama. ${ }^{13}$ Masyarakat dibantu untuk menyadari bahwa dalam konflik Poso, bukan hanya satu kelompok saja yang menjadi korban tetapi kedua kelompok menjadi korban bersama-sama. Dalam konflik tersebut masyarakat Poso secara keseluruhanlah yang menjadi korban. Kalah jadi abu tetapi menang jadi arang, kedua-duanya menjadi korban dan tidak ada yang diuntungkan sama sekali. Kedua kelompok yang bertikai berada dalam kesetaraan yaitu sama-sama telah menjadi korban.

Ingatan dan pemahaman tentang "kitorang sudah sama-sama menderita" menjadi pengingat bahwa konflik adalah tentang kehilangan kehidupan. Sama-sama menjadi korban, dikorbankan dan mengorbankan. Keterlibatan masyarakat dalam konflik sebenarnya bentuk tidak berdayaan masyarakat dihadapan pihak-pihak yang berkepentingan dan diuntungkan oleh konflik Poso. Pemaknaan yang baru ini menjadi pendorong bagi masyarat Poso untuk kembali mengangkat rasa kemanusiaan masyarakat Poso yang telah menjadi korban. Dengan kesadaran ini ruang-ruang bersama untuk

13 Ibid, 169.
12 Ibid,128. 
saling bertemu antara dua kelompok menjadi lebih dimungkinkan.

Pengalaman Lian Gogali dari konflik Poso mengingatkan kita bahwa ruang bersama, tempat bertemunya berbagai perbedaan tidak saja dibutuhkan untuk mencegah konflik tetapi juga di saat konflik dan setelah konflik. Bahkan lebih jauh dari pada itu, ruang bersama dalam perbedaan harus dimulai sejak dari dalam pemikiran kita, bagaimana kita memilih pemahan dan memilih ingataningatan dari pengalaman kita terhadap perbedaan bersama.

\section{Misi Rekonsiliasi}

Di tengah keadaan Indonesia yang sangat beragam ini, gerejagereja Indonesia tidak dapat tinggal diam. Gereja tidak dapat membiarkan agama yang sejatinya pembawa pesan damai dipakai oleh berbagai kepentingan justru sebagai pemantik konflik. Kesadaran untuk menciptakan ruang-ruang bersama dalam perbedaan hendaknya juga menjadi bagian dari teologi dan pergumulan hidup bergereja.

Widi Artanto, seorang misiolog menjelaskan bahwa konsep-konsep misi yang diterima dan diteruskan oleh gereja-gereja di Indonesia harus disesuaikan dengan situasi dan kondisi Indonesia. Di tengah masyarakat yang sangat beragam, gereja harus mendefinisikan makna kehadirannya sebagai pembawa misi Allah. Artanto kemudian menawarkan lima tema misi utama bagi gerejagereja di Indonesia. Salah satu tema misinya adalah misi rekonsiliasi sebagai misi di tengah konteks Indonesia yang sangat beragam..$^{14}$

Bagi Artanto, rekonsiliasi mengandung arti perdamaian atau perukunan. Tema ini sendiri sebenarnya sudah sering dipakai oleh gereja-gereja di Indonesia sejak tahun 1960. Gereja tidak hadir untuk dirinya sendiri, kehadiran gereja haruslah mewujud nyatakan misi Allah bagi dunia ini. Misi rekonsiliasi yang dilaksanakan oleh gereja sebenarnya adalah misi Allah sendiri. Allah telah terlebih dahulu yang melakukan rekonsiliasi. Pada hakikatnya pendamaian dan rekonsiliasi, adalah pemulihan hubungan relasi yang menyeluruh yang menyeluruh antara Allah dan manusia dan segala ciptaanNya. Rekonsiliasi yang paling nyata dilakukan oleh Allah adalah dengan menjadi manusia di dalam Yesus yang bersedia mati di kayu salib. Setelah kematian Yesus, rekonsiliasi diteruskan oleh Roh Kudus yang selalu menyertai manusia. Selalu ada ruang bersama antara Allah dan manusia yang tidak pernah kosong sepanjang sejarah, selalu terisi sejak dari cerita penciptaan, penebusan, hingga penyertaan saat ini.

Dalam melaksanakan misi rekonsiliasi salah satu tema yang perlu mengalami pemaknaan kembali adalah kata penginjilan. Di tengah konteks Indonesia yang beragam, penginjilan tidak hanya dapat dimaknai sebagai pengkristenan atau sekedar menambah jumlah anggota gereja. Tujuan

${ }^{14}$ Widi Artanto, Menjadi Gereja Misioner, (Yogyakarta: Kanisius, 1997) 
utama penginjilan adalah pemenuhan Kerajaan Allah. Gereja hadir untuk melakukan misi Allah karena itu seluruh keberadaan gereja diperuntukan bagi hadirnya Kerajaan Allah. Kehadiran gereja tidak untuk kepentingan dirinya sendiri. Kata penginjilan harus dimaknai dalam gambaran besar misi menghadirkan Kerajaan Allah di tengah konteks Indonesia yang beragam.

Dalam konteks yang beragam, penginjilan dipahami sebagai kesempatan bagi manusia untuk memahami rekonsiliasi dengan Allah. ${ }^{15}$ Rekonsiliasi dengan Allah tidak hanya dipahami sebagai rekonsiliasi pribadi tetapi juga dipahami dalam konteks keadilan dan perdamaian. Keadilan dan perdamaian tidak dapat terpisahkan sebab perjuangan melawan ketidakadilan dan pembebasan dari penindasan tidak bertujuan pada pembalasan tetapi demi keadilan dan perdamaian. Mewujudkan keadilan perdamaian di Indonesia tentunya tidak dapat dilakukan oleh gereja-gereja tanpa bekerja sama dengan berbagai pihak terutama umat beragama lain. Dalam kerja sama dengan berbagai pihak yang berbeda, kita tidak hanya menyatakan keyakinan kita tetapi juga ditantang untuk mampu mendengar dari orang lain dan diperkaya oleh perbedaan yang ada. Oleh karena itu penginjilan dapat dipahami sebagai proses meyediakan ruang bersama dalam perbedaan yang saling

15 Widi Artanto, Menjadi Gereja Misioner, (Yogyakarta: Kanisius, 1997) 233. memperkaya demi hadirnya Kerajaan Allah. ${ }^{16}$

Kebersamaan dengan berbagai pihak yang berbeda untuk mewujudkan keadilan dan perdamaian dapat menjadi ruang bersama dalam perbedaan. Keterlibatan gereja baik sebagai pribadi dan lembaga dalam praktek-praktek solidaritas sosial di tengah kemiskinan, kelaparan, perbudakan, dan masalah sosial lainnya adalah keharusan. Gerejagereja tidak dapat sibuk dengan diri sendiri, membangun fisik bangunan gereja yang megah, sibuk untuk mengatur organisasi sendiri, sibuk dengan berbagai doktrin tentang surga hingga kehabisan tenaga untuk terlibat dengan masalah yang ada dalam masyarkat.

Pemaknaan misi rekonsiliasi sebagai bagian dari mewujudkan Kerajaan Allah juga menjadi peringatan bagi keberagaman di dalam gereja sendiri. Keberagaman adalah salah satu hakikat gereja yang tidak bisa disangkal. Di dalam kekristenan sendiri terdapat banyak sekali aliran dengan berbagai perbedaan ajaran dan ritualnya. Perbedaan-perbedaan di dalam kekristenan sendiri harus dikelola sedemikian rupa sehingga menjadi sumber damai sejahterah dan bukan kustru menjadi sumber perpecahan. Kurangnya keterlibatan gereja dalam isu-isu sosial bersama dengan agama lain terkadang juga dipengaruhi karena gereja sibuk bertikai dengan gereja-

\footnotetext{
16 World Council of Churches, Dokumen Misi: Together Towards Life: Mission and Evangelism in Changing Landscape, 15.
} 
gereja lainnya yang berbeda. Ruang bersama dalam perbedaan juga menjadi kebutuhan dalam diri gereja sendiri.

Salah satu langkah utama dari misi rekonsiliasi adalah dialog bersama dalam keberagaman. Dialog dalam keberagaman, berati kita menghargai pluralitas bangsa. Dengan menghargai pluralitas tidak berarti kita lalu mengatakan bahwa semua agama adalah sama. Setiap orang diberi kebebasan untuk percaya dan menjalankan tradisi keagamaannya dengan menjadi sumber kebaikan, keadilan, kesejahteraan dan perdamaian. ${ }^{17}$ Dialog menuntut agar setiap pihak yang terlibat tidak hanya menghargai sesama tetapi juga bersedia untuk berlaku adil kepada orang lain, menciptakan perdamaian dan saling menghormati.

Dialog ini sebenarnya juga menjadi ruang bersama bagi keberagaman di dalam gereja maupun keberagaman di masyarakat. Artanto membagi dialog menjadi tiga tahap: ${ }^{18}$

1. Dialog kehidupan antar umat beriman. Dialog yang dikembangkan dalam kehidupan sehari-hari melalui pemenuhan kebutuhan bersama sebagai manusia. Saling membutuhkan dan saling berbagi dalam pergaulan, merayakan suka, dan menjalani duka dalam keseharian dengan mereka yang berbeda iman.

17 Elga Joan Sarapung, Menegaskan tentang pluralisme agama: Prospek pluralisme agama di Indonesia, (Jogjakarta: Interfidei, 2009)xvii.

18 Artanto, Menjadi Gereja Misioner, 237.
2. Dialog teologis antar iman. Dialog ini membicarakan titik temu dan titik pemisah dari keberagaman yang ada. Ketika melakukan dialog ini, para peserta harus saling menghargai. Rasa saling menghargai bisa ada jika masing-masing peserta memahami dengan baik ajaran agamanya dan juga ajaran agama yang berbeda. Dengan pemahaman yang baik rasa saling menghargai akan bertumbuh.

3. Dialog dalam aksi bersama. Dialog ini dilakukan secara bersama-sama melakukan aksi nyata untuk menjawab masalah-masalah sosial.

Tiga tahapan dialog ini menunjukan bahwa dialog sebagai ruang bersama dalam perbedaan harus dihidupi sebagai bagian integral dari kehidupan berbangsa dan bernegara di Indonesia. Dialog bersama bukan hanya milik para pemuka agama atau para pejabat tetapi juga dilaksanakan oleh masyarakat dalam kehidupan sehari-hari. Indonesia adalah rumah bersama dalam perbedaan dan ruang bersama dalam perbedaan adalah cara mempertahankan Indonesia menjadi rumah yang adil dan damai. 


\section{DAFTAR PUSTAKA}

Artanto,Widi. Menjadi Gereja Misioner, (Yogyakarta: Kanisius, 1997)

Gogali, Lian. Konflik Poso: Suara Perempuan dan Anak Menuju Rekonsiliasi Ingatan, (Yogyakarta: Galang Pers, 2009)

Hardiman, F. Budi. Massa, Teror, dan Trauma, (Yogyakarta: Lamalera, 2011)

Putrani, Basilica Dyah. Perempuan, Konflik, dan Rekonsiliasi, (Jakarta: Gunung Mulia, 2016)

Sarapung, Elga Joan. Menegaskan tentang pluralisme agama: Prospek pluralisme agama di Indonesia, (Jogjakarta: Interfidei, 2009)xvii.

World Council of Churches, Dokumen Misi: Together Towards Life: Mission and Evangelism in Changing Landscape.

Yewangoe, A. A. Agama dan Kerukunan, (Jakarta: Gunung Mulia, 2011)

Perempuan penyebar kebencian resmi ditahan, https://www.nttnews.com/2017/05/15/perempua n-penyebar-ujaran-kebencianresmi-ditahan/. 15 Mei 2017, diakses 31 Agutus 2017.

Tarik Laporan, Brigader Meo Maafkan Prima Gaida Journalita, https://www.nttnews.com/2017/06/07/tariklaporan-brigade-meo-maafkanprima-gaida-journalita/. 7 Juni 2017, diakses 31 Agutus 2017. Laporan Kebebasan Beragama dan Berkeyanikan 2015. http://wahidfoundation.org/index. php/publication/detail/LaporanKebebasan-Beragama-danBerkeyakinan-KBB-2015, diakses 31 Agustus 2017. 